African Crop Science Journal by African Crop Science Society is licensed under a Creative Commons Attribution 3.0 Uganda License. Based on a work at www.ajol.info/ and www.bioline.org.br/cs DOI: https://dx.doi.org/10.4314/acsj.v29i2.4

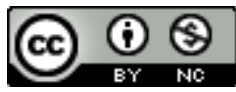

\title{
FARMERS' PREFERENCE FOR ONION VARIETIES AND IMPLICATIONS OF KNOWLEDGE OF IRIS YELLOW SPOT DISEASE IN KENYA
}

\author{
R.K. BIRITHIA, S. SUBRAMANIAN ${ }^{1}$ and D.K. KURIA \\ Agricultural Sciences Department, Karatina University, P. O. Box 1957-10101, Karatina, Kenya \\ ${ }^{1}$ International Centre of Insect Physiology and Ecology, P. O. Box 30772-00100, Nairobi, Kenya \\ Corresponding author: birithia@gmail.com
}

(Received 10 January 2021; accepted 31 March 2021)

\begin{abstract}
Thrip transmitted Iris yellow spot disease (IYSD) is an economically important viral disease, affecting bulb onions worldwide. Recommended IYSD resistant varieties are not commonly grown in countries like Kenya, yet inappropriate disease control measures are applied upon disease occurrence in the fields. This is presumably due to lack of knowledge on the disease and/or recommended varieties do not match farmers' preferred traits. The objective of this study was to assess farmers' knowledge of IYSD and their criteria for selecting onion varieties for/against IYSD in Kenya. A study was conducted with 360 respondents across three onion growing agro-ecological zones (AEZ) in Kenya, during 20192020. Farmers' fields were assessed for IYSD incidence and severity. All farmers acknowledged the existence of IYSD based on diseased plants in the field. However, majority of the farmers (95.6\%) were not aware of the cause of the disease. Onion thrips and IYSD susceptible red onion varieties were the most preferred (77.9\%) by farmers. Preference for these varieties was based on their high yielding capacity, early maturity, strong pungency, marketability and long shelf life. Most farmers (59.8\%) relied on fungicides to control IYSD, though ineffectively. Lack of appropriate management strategies for IYSD was due to lack of knowledge on the disease diagnosis, epidemiology as well as cultivation of IYSD susceptible red varieties.
\end{abstract}

Key Words: Epidemiology, fungicides, onion thrips, vectors

\section{RÉSUMÉ}

La maladie des taches jaunes de l'iris (IYSD) transmise par le thrip est une maladie virale économiquement affectant les oignons à bulbe dans le monde entier. Les variétés résistantes qui sont recommandées à l'IYSD ne sont pas couramment cultivées dans des pays comme le Kenya, mais des mesures de lutte contre la maladie inappropriées sont appliquées en cas d'apparition de la maladie dans les champs. Cela est probablement dû au manque de connaissances sur la maladie et / ou les variétés recommandées ne correspondent pas aux caractéristiques préférées des agriculteurs. L'objectif de cette étude était d'évaluer les connaissances des agriculteurs sur l'IYSD et leurs critères de sélection des variétés d'oignon pour / contre l'IYSD au Kenya. Des entretiens structurés ont été menés avec 360 personnes 
interrogées dans trois zones agroécologiques (AEZ) de culture d'oignon au Kenya, au cours de la période 2019-2020. Les agriculteurs ont été sélectionnés au hasard et leurs champs ont été évalués pour l'incidence et la gravité de l'IYSD. Tous les agriculteurs enquêtés ont reconnu l'existence de l'IYSD sur la base des plantes malades qui leur ont été montrées sur le terrain. Cependant, la majorité des agriculteurs $(95,6 \%)$ ne connaissaient pas la cause de la maladie. Les thrips de l'oignon et les variétés d'oignon rouge sensibles à l'IYSD étaient les plus appréciées (77,9\%) par les agriculteurs. La préférence pour ces variétés était basée sur leur capacité de rendement élevée, leur maturité précoce, leur fort piquant, leur aptitude à la commercialisation et leur longue durée de conservation. La plupart des agriculteurs $(59,8 \%)$ se sont appuyés sur des fongicides pour lutter contre l'IYSD, bien que de manière inefficace. Le manque de stratégies de gestion appropriées pour l'IYSD était dû au manque de connaissances sur le diagnostic de la maladie, l'épidémiologie ainsi que la culture de variétés rouges sensibles à l'IYSD.

Mots Clés: Epidémiologie, fongicides, thrips de l'oignon, vecteurs

\section{INTRODUCTION}

Dry bulb onion (Allium cepa L.) is one of the highly consumed vegetable in the world due to its richness in carbohydrates, vitamins, minerals and their medicinal properties (Griffith et al., 2002; Pareek et al., 2017). In Kenya, onions are grown mainly by small-holder farmers for local consumption and export. Although the area under onion production in the country has increased over the last decade, yields per unit area remain low; averaging 14.3 metric tonnes per hectare; compared to leading producers such Spain $\left(54.1 \mathrm{t} \mathrm{ha}^{-1}\right)$, Australia $\left(54.2 \mathrm{t} \mathrm{ha}^{-1}\right)$, USA $\left(54.4 \mathrm{t} \mathrm{ha}^{-1}\right)$ and Korea (63.5 $\mathrm{t} \mathrm{ha}^{-1}$ ) (FAOSTAT, 2016). The low yields are attributed to insect pests such as onion thrips plus their transmitted disease known as Iris yellow spot disease (IYSD).

Onion thrips (Thrips tabaci Lindeman), transmitted Iris yellow spot disease (IYSD) (family Bunyaviridae, genus Tospovirus), is the most devastating onion viral disease known worldwide (Pappu et al., 2009; Mandal et al., 2012). Tospoviruses cause annual yield losses of about US $\$ 1$ billion worldwide (Pappu et al., 2009). IYSD infection induce symptoms such as leaf distortion, streaking and stunting, lesions, vein clearing and mosaic to the infected plants that reduce the photosynthetic area leading to reductions in yield (Gent et al., 2006).
IYSD incidence of up to $75 \%$ on the infected fields has been reported in Kenya, with onion thrips and the disease affecting many varieties commonly grown in East African region (Kibayu, 2009; Birithia et al., 2014). To manage the disease, farmers are encouraged to plant onion thrips and IYSD resistant onion varieties, but successful adoption is dependent on the presence of famers preferred traits among the available varieties. Sometimes, the recommended varieties are disapproved by farmers because of mismatch with their preferred characteristics.

Knowledge about IYSD epidemiology is vital in controlling the spread of the disease, since there are no antiviral products presently on the markets (Schreinemachers et al., 2015). If appropriate control measures are not implemented, IYSD can result to complete loss of onion crop (Pappu et al., 2009). Previous studies have shown that low knowledge on plant viral diseases among farmers resulted in implementation of wrong management strategies and subsequent yield losses (Karavina et al., 2017). It is, therefore, crucial to understand the level of farmers' awareness of IYSD, their perceptions about how infection affects onion yields, how they manage the disease and their criteria for selecting onion varieties against IYSD. Creating awareness among farmers is among the most important 
strategies for controlling IYSD; however, this will only be possible if we understand the current state of farmers' knowledge on the subject.

The objective of this study was to assess farmers' knowledge of IYSD and their criteria for selecting onion varieties for/against IYSD in Kenya.

\section{MATERIALS AND METHODS}

Study site. This study was conducted in three agro-ecological zones (AEZ) of Kenya; namely high-altitude region in Nakuru County, mid altitude region in Nyeri and Kajiado Counties, and low altitude region in Makueni County; where onions are widely cultivated (MOA, 2018). We selected seven rural villages across the three AEZ; namely, Mai mahiu and Naivasha in Nakuru County, Kieni and Karatina in Nyeri County, Kimana and Mbirikana in Kajiado County and Emali in Makueni County (Table 1). The study areas are characterised by a tropical climate and have a bimodal rainfall pattern between 800 and $1400 \mathrm{~mm}$ annually. The regions experience warm to hot temperatures, ranging from 15 to $30{ }^{\circ} \mathrm{C}$. The study sites are located on well drained humic soils.

Sampling and data collection. A multi-stage sampling method was used to select farmers for participation in the interviews. In the first stage, we selected one rural village in low altitude AEZ, four rural villages in mid altitude
AEZ and two rural villages in high altitude AEZ. Selection of the number of rural villages was based on their relative importance in onion production. In the second stage, we randomly sampled 45 to 54 households per rural village depending on the Hamed (2017) formula:

$n=\frac{\mathrm{P}(100-\mathrm{P}) \mathrm{Z}^{2}}{\mathrm{E}^{2}}$

Where:

$n$ is the required sample size, $\mathrm{P}$ is the proportion of interviewed farmers who recognised IYSD symptoms in their farm; $E$ is the percentage maximum error required; and $\mathrm{Z}$ is the value corresponding to level of confidence required set at $5 \%$.

Application of this formula gives $\mathrm{N}=360$ farmers, of which 105 were sampled in high altitude AEZ, 210 were in mid altitude AEZ and 45 were in low altitude AEZ (Table 1). Identification of responding households was facilitated by sub-county agricultural extension officers and/or village leaders.

Information on farmers' knowledge of IYSD, varieties grown and criteria for their preference was collected using semistructured questionnaire. The questionnaire was pretested on 15 farmers in each AEZ in a location distant from the intended sites of the study, to ensure clarity of information sought. All interviews were conducted in Kiswahili/ local language, which was locally used by the communities in the study areas. Assessment

TABLE 1. Areas involved in the Iris yellow spot disease study across three onion growing agroecological zones in Kenya

\begin{tabular}{lllll}
\hline Agro-ecological zone & Low altitude & \multicolumn{2}{c}{ Mid altitude } & High altitude \\
\hline County & Makueni & Kajiado & Nyeri & Nakuru \\
Rural villages & Emali & $\begin{array}{l}\text { Kimana } \\
\text { Mbrikana }\end{array}$ & $\begin{array}{l}\text { Kieni } \\
\text { Karatina }\end{array}$ & $\begin{array}{l}\text { Naivasha } \\
\text { Mai mahiu }\end{array}$ \\
No. of households surveyed & 45 & 108 & 102 & 105 \\
\hline
\end{tabular}


of farmers' knowledge of IYSD was done with IYSD infected plants in the field as described by Schreinemachers et al. (2015). To evaluate farmers' criteria in their selection of onion varieties, farmers were asked to list the characteristics that an onion variety must have in order to be widely adopted in their area. They were further asked to rank these selection criteria according to their importance.

IYSD incidence and severity score in their fields were assessed by conducting field observations as described by Kritzman et al. (2001). Field visits were carried out in the study sites to verify the correlation between farmers' knowledge with the incidence and severity of IYSD. Three onion fields containing plants grown for two months and at least $15 \mathrm{Km}$ apart, were surveyed in each rural village. Disease severity was scored on 30 plants along two diagonals of the field, on scale of 1-5 as described by Kritzman et al. (2001); where, $1=$ no damage; $2=$ minor damage $(10-$ $30 \%$ leaf damage); $3=$ moderate damage (31$50 \%$ leaf damaged); $4=$ severe damage (51$75 \%$ leaf damaged); and $5=$ total crop damage (76-100\% leaf damaged).

Disease incidence was determined by dividing the number of infected plants by the total number of observed plants.

Where:

IYSD incidence $(\%)=$

Number of infected plants per plot x 100 Total plants per plot

Data analysis. Data collected were analysed using Statistical Software for Social Sciences (SPSS). Frequency distribution was determined on four socio-demographic factors; farmers age, education level and years of experience in growing onion. Chi-square was used to test relationships between farmers' knowledge of IYSD and the sociodemographic factors.

Separate Chi-square tests were used to assess whether farmers' preferences for a particular variety were related to the AEZ in which they lived and whether these characteristics were present in their preferred varieties. Additionally, data on Iris yellow spot disease incidence and severity were subjected to Chi-square tests at $95 \%$ significance, using $\mathrm{R}$ package version 2.10 using packages "Rcmdr version 1.5-3" (Fox et al., 2009).

\section{RESULTS}

Socio-demographic characteristics. Table 2 provides the socio-demographic characteristics of the onion farmers involved in the survey. Most of the interviewed farmers were male $(66.4 \%)$, majority were $>36$ years $(80.2 \%)$ and most were married $(87.5 \%)$. Majority of onion farmers (84.5\%) had attained secondary level of education, with $53.5 \%$ of farmers having had at least 10 years of experience in onion production (Table 2).

Recognition of Iris yellow spot disease. All farmers surveyed acknowledged existence of IYSD in their fields based on diseased plants shown to them in the field. However, only $4.4 \%$ of farmers were aware of the cause and the vectors of the disease. Most farmers (72.4\%) believed that IYSD was caused by fungal pathogens; while $23.2 \%$ mentioned nutrient deficiencies as the causal agents. Majority of the farmers (77.5\%) believed, based on their observations in their fields, that IYSD reduces onion bulb size. A Chi-square test suggested that recognition of IYSD symptoms did not depend on a farmer's age, gender, education or years of experience on onion growing (Table 3 ).

Source of onion seeds and farmers' action against IYSD. Majority of the farmers (78.8\%) obtained onion seeds from local shops/agro vets. Only $3.75 \%$ of the farmers acquired seeds from registered and certified onion seed sources, such as Kenya Seeds Company and Sim Law Seeds Company; while $17.5 \%$ sourced for onion seedlings from the neighbours (Fig. 1a). Analysis of independence 
TABLE 2. Socio-demographic characteristics of onion growers in the selected rural villages of Kenya

\begin{tabular}{llc}
\hline Socio-demographic characteristics & Modality & Frequency (\%) \\
\hline Sex & Male & 66.4 \\
& Female & 33.6 \\
Age & $<18$ years & 8.1 \\
& $19-35$ years & 11.7 \\
& $>36$ years & 80.2 \\
Marital status & Married & 87.5 \\
& Single & 8 \\
Education level & Widow/er & 4.5 \\
& Primary & 12.3 \\
& Secondary & 84.5 \\
Experience in onion production & Tertiary & 3.2 \\
& $<3$ years & 10.3 \\
& $4-10$ years & 53.5 \\
& $>10$ years & 36.2 \\
\hline
\end{tabular}

TABLE 3. Chi-square tests of the relationship between Kenyan onion farmers' knowledge of Iris yellow spot disease and socio-demographic factors in Kenya

\begin{tabular}{llll}
\hline Factors & $\chi^{2}$ & $d d l$ & $\mathrm{P}$ \\
\hline Gender & 1.65 & 1 & $0.24 \mathrm{NS}$ \\
Age & 0.89 & 1 & $0.35 \mathrm{NS}$ \\
Education & 3.64 & 3 & $0.40 \mathrm{NS}$ \\
Farming experience & 0.1 & 2 & $0.56 \mathrm{NS}$ \\
\hline
\end{tabular}

$d d l=$ degree of liberty, $\mathrm{P}=$ probability, $\mathrm{NS}=$ not significant at $5 \%$ threshold

revealed that the source of onion seeds was significantly related to $\mathrm{AEZ}\left(\chi^{2}=49.32, \mathrm{P}=\right.$ $0.001)$. Majority of the respondents $(96.4 \%)$ relied on visual symptoms on onion plants for IYSD diagnosis.

Lack of appropriate IYSD control measures was noted in this study as only $4.5 \%$ of interviewed farmers rouged and buried IYSD infected plants; while $12.5 \%$ of the farmers used insecticides to control onion thrips, the disease vectors (Fig. 1b). Majority of the farmers $(59.8 \%)$ reported having applied fungicides to control IYSD, though ineffectively (Fig. 1b). A significant number of the farmers (23.2\%) did not use any control measures against IYSD.

\section{Farmer criteria for selecting of onion} varieties. Eight onion varieties were commonly grown by farmers across the rural villages surveyed in Kenya. Of these, seven were red varieties (Jambar F1, Islero, Red creole, Red passion, Red pinnoy, Bombay red, Red tropicana) and one white variety (Texas grano). Red onion varieties were the most preferred $(77.9 \%)$ mainly in low and mid altitude AEZ; while $12.1 \%$ of the farmers in high altitude AEZ, preferred Texas grano, a 
(a)

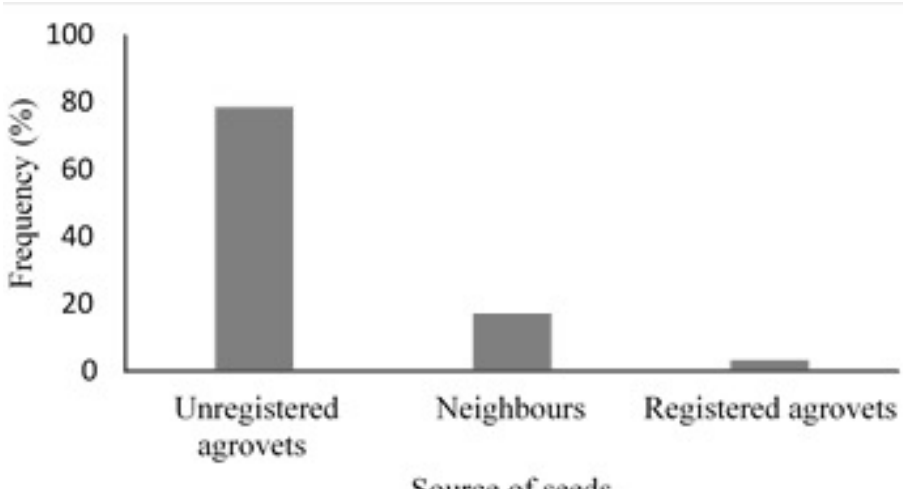

(b)

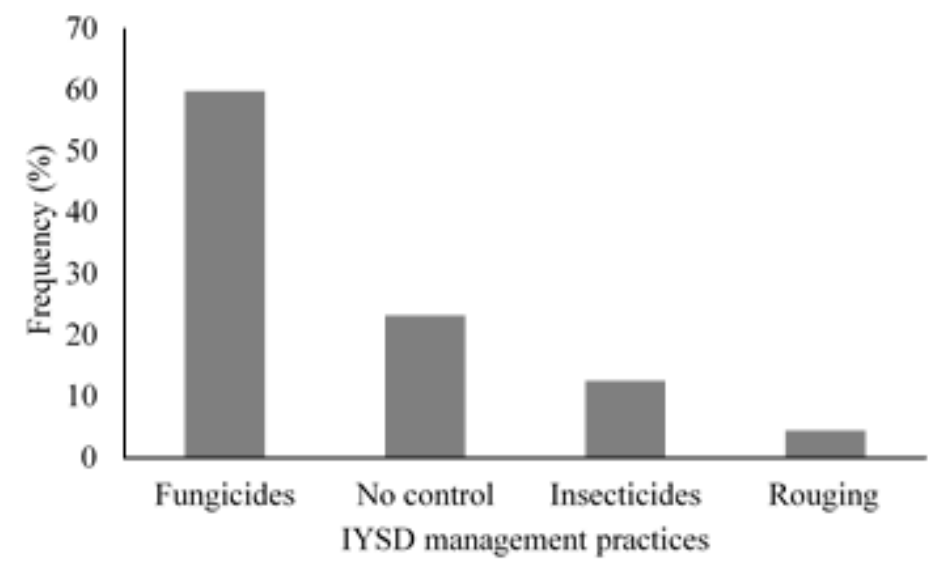

Figure 1. (a) Sources of onion planting material, (b) Iris yellow spot disease management practices in selected rural villages in Kenya.

moderately resistant variety to onion thrips and IYSD (Table 4). The study revealed that farmers prioritised the following characteristics when selecting red onion varieties; namely high yielding/large bulb size, early maturity, strong pungency, marketability and long shelf life. Preference for Texas grano, white onion variety was based mainly on their high yielding capacity and pest and disease resistance. However, there was low adoption of this variety due to its high perishability, mid pungency and low preference among the consumers. A Chi-square test showed that a farmer's preferred characteristics for onion variety were significantly related to the AEZ in which he/she lived $\left(\chi^{2}=23.16, d d l=\right.$ $2, \mathrm{P}=0.01 \%)$. A separate Chi-square test showed that a farmers' preferred characteristics were also significantly related to a farmer's preferred variety $\left(\chi^{2}=45.09, d d l\right.$ $=7, \mathrm{P}=0.01$ ).

Incidence and severity of IYSD. The assessment of IYSD incidence based on rural villages showed that Emali was the most affected $(82.4 \%)$, followed by Kimana (78.5\%), Mbirikana (74.5\%), Kieni (70.3\%), Karatina (70.2\%), Mai Mahiu (38.5\%) and Naivasha (32.9\%) (Fig 2a). Among the three AEZ surveyed, disease incidence was highest in low altitude AEZ, followed by mid altitude AEZ; while the least incidence was recorded in high altitude AEZ (Fig. 2b). Chi-square tests showed that differences in the distribution of IYSD were more significant by AEZ than by rural villages $(\mathrm{P}<0.001)$ (Table 5). 
TABLE 4. Preferred onion varieties by farmers in selected rural villages in Kenya

\begin{tabular}{llcl}
\hline Agro-ecological zone & Rural villages & $\begin{array}{c}\text { Number of varieties } \\
\text { grown in the selected } \\
\text { rural villages }\end{array}$ & Preferred varieties \\
\hline Low & Emali & 4 & $* * *$ Red creole, **Red pinnoy \\
Mid & Kimana & 3 & $* * *$ Red creole, **Bombay red \\
Mid & Mbirikana & 3 & $* * *$ Red pinnoy, **Jambar FI \\
Mid & Kieni & 4 & $* * *$ Islero, $* *$ Red creole \\
Mid & Karatina & 4 & $* * *$ Red passion, **Islero \\
High & Naivasha & 1 & $* * *$ Texas grano \\
High & Mai Mahiu & 1 & $* * *$ Texas grano \\
\hline
\end{tabular}

*** Preferred by at least $75 \%$ of the farmers in the rural villages; $* *$ preferred by at least $50 \%$ of the farmers in the rural villages

The highest disease severity score (4.51) was recorded in Emali and Kimana, closely followed by Mbirikana (4.43), Kieni (4.32) and Karatina (3.75) (Fig. 3a). Mai mahiu and Naivasha rural villages were the least affected, with disease severity score of 1.51 and 1.42 ; respectively. Low altitude AEZ recorded the highest disease severity; while high altitude AEZ had the least disease incidence (Fig. 3b) Chi-square tests showed that differences in the severity of IYSD were more significant by AEZ than by the rural villages $(\mathrm{P}<0.001)$ (Table 6).

\section{DISCUSSION}

Findings of this study have shown that most onion farmers (95.6\%) in Kenya lacked critical knowledge about IYSD identification and epidemiology based on diseased plants in their fields. This resulted in majority of the onion growers (59.8\%) using fungicides to combat IYSD; though ineffectively. This lack of knowledge constitutes partly the major obstacle for IYSD control in the country. According to Karavina et al. (2017), correct tospovirus identification is crucial for appropriate management of the viral disease. These findings concur with the earlier studies by Nagaraju et al. (2002) in Karnataka, who found that only $2 \%$ knew that the tomato leaf curl virus disease was transmitted by whiteflies. Similarly, Nabuzale (2014) reported low knowledge of tomato spotted wilt virus among farmers in Tanzania. In the present study a few farmers $(4.4 \%)$ who were trained on IYSD identification were able to differentiate IYSD diseased and healthy onion plants. Thus, onion farmers should be sensitised on the epidemiology and symptoms of IYSD, in order to be able to take appropriate control measures of the disease in their fields and minimise its spread to neighbouring fields.

Majority of onion farmers (96.4\%) depended on visual symptoms assessment for IYSD diagnosis. This is unreliable, since IYSD produces symptoms that are similar to those caused by other pathogens and/or abiotic factors (Schreinemachers et al., 2015). Additionally, mixed pathogen infections on the same plants can result in complex symptoms causing identification of the pathogen based on symptoms alone difficult (Syller, 2012). Therefore, farmers should be advised to take diseased plant samples for confirmatory tests in plant clinics.

A few farmers $(4.5 \%)$ rogued and buried IYSD infected plants; while only $12.5 \%$ used insecticides to control onion thrips. Majority of the farmers $(59.8 \%)$ confused IYSD symptoms with fungal disease; thus using fungicides in an attempt to combat the menace, 
(a)

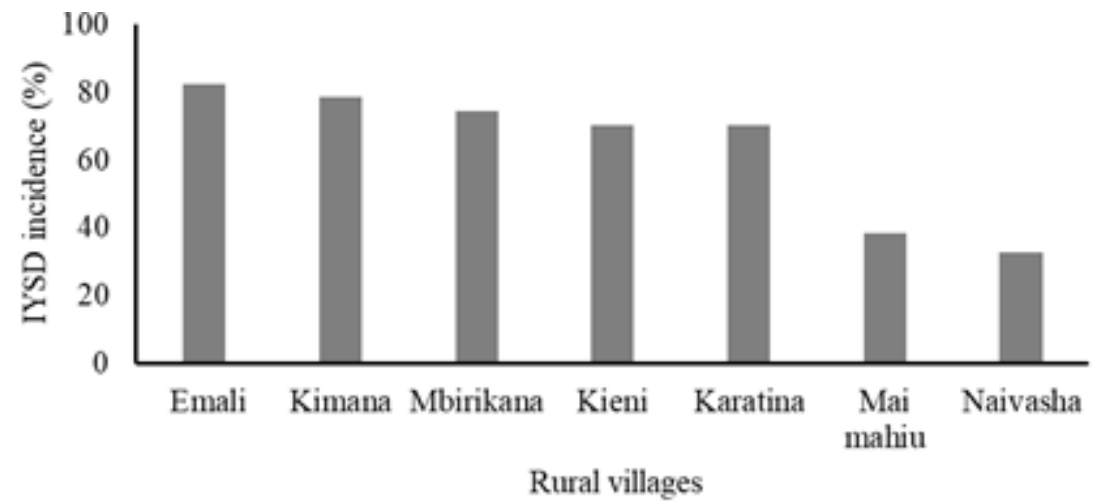

(b)

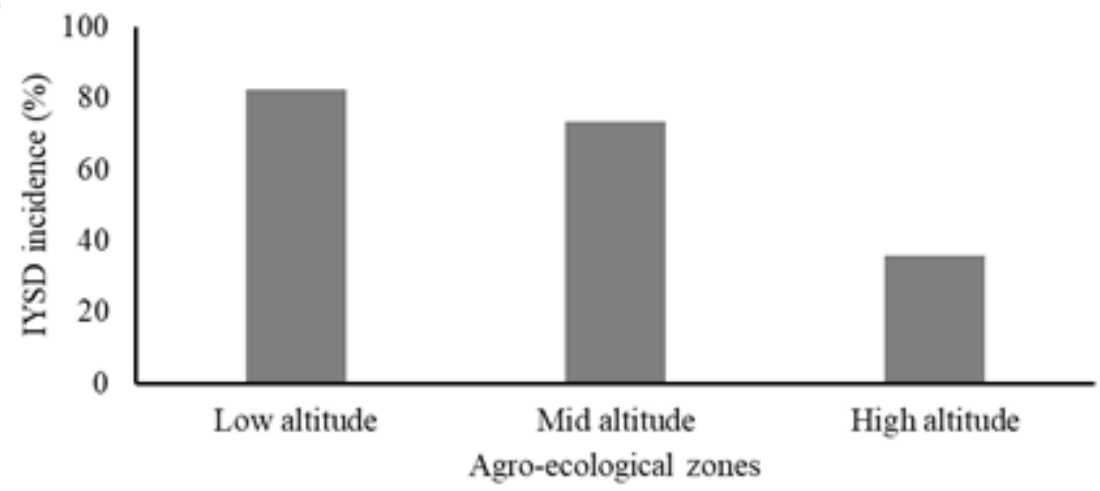

Figure 2. Iris yellow spot disease incidence by (a) Rural villages and (b) Agro-ecological zones in Kenya.

TABLE 5. Chi-square test of Iris yellow spot disease incidence in selected onion growing agroecological zones and selected rural villages in Kenya

\begin{tabular}{lclll}
\hline & ddl & Log- & $\chi^{2}$ & $P$ \\
\hline Ord. Orig. & 1 & -330.91 & & \\
Agro-ecological zone & 2 & -313.35 & 37.13 & $<0.0001$ \\
Rural villages & 6 & -298.81 & 19.08 & $<0.0001$ \\
\hline
\end{tabular}

TABLE 6. Chi-square test of the severity of Iris yellow spot disease in the selected agro-ecological zones and rural villages

\begin{tabular}{lclll}
\hline Ord. Orig & ddl & Log- & $\chi^{2}$ & $P$ \\
\hline Agro-ecological zone & 2 & -233.18 & 23.16 & $<0.0001$ \\
Rural villages & 6 & -118.6 & 19.12 & $<0.0001$ \\
\hline
\end{tabular}


(a)

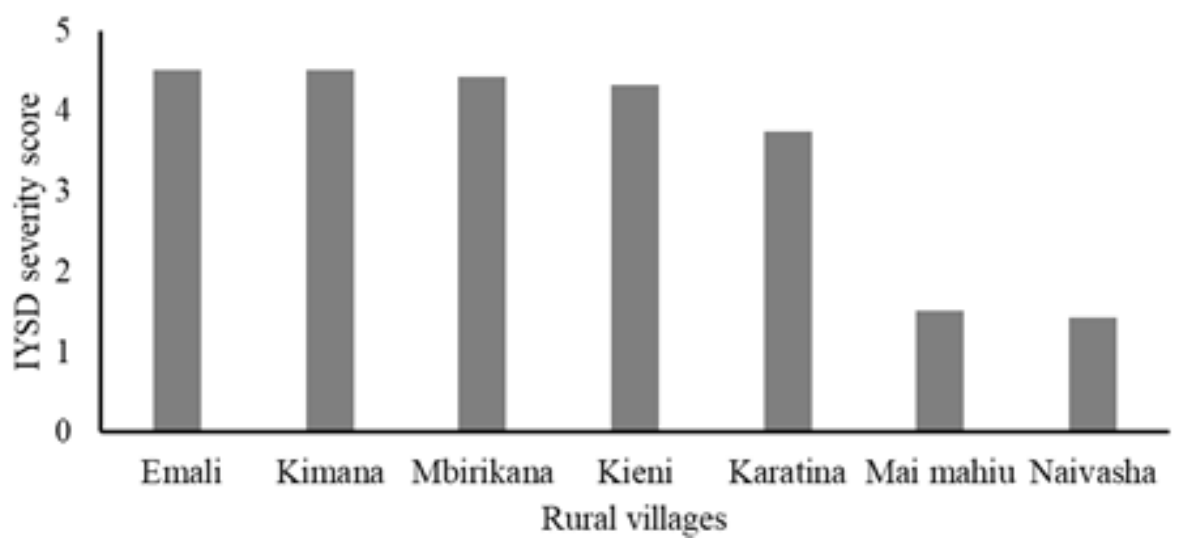

(b)

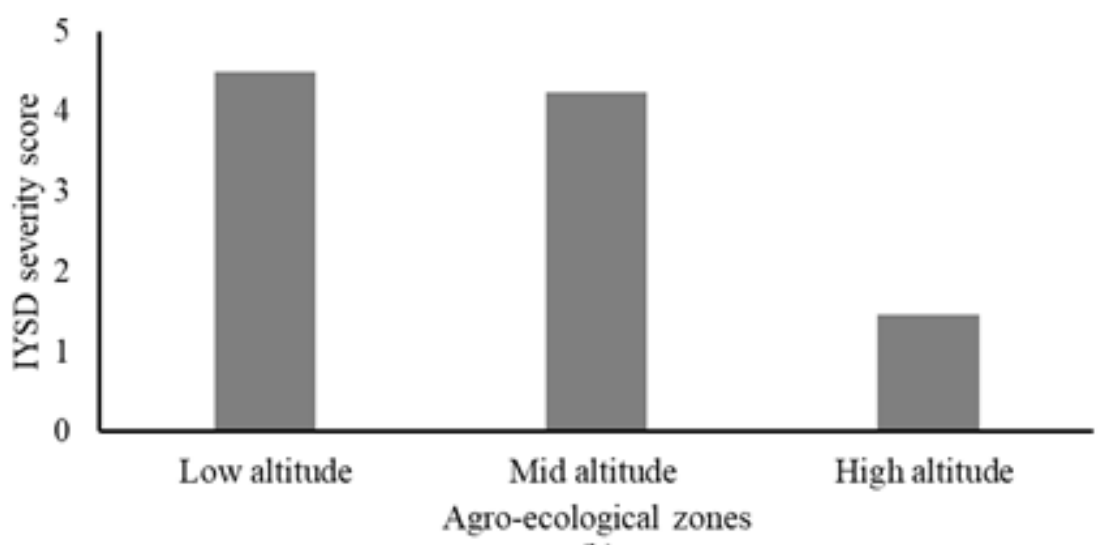

Figure 3. Severity of Iris yellow spot disease by (a) Rural villages and (b) by onion growing agroecological zones of Kenya.

though unsuccessfully. This underscores the wide farmer knowledge gap, particularly in identifying IYSD, undertaking epidemiology and administering disease management strategies. Being able to distinguish symptoms of virus infections from other diseases; and knowledge that IYSV are transmitted by thrips may encourage farmers to control onion thrips populations and avoid the unnecessary use of fungicides. Schreinemachers et al. (2015) also reported poor knowledge of begoviruses among farmers in India, Thailand and Vienan. Similarly, Karavina et al. (2017) reported wide misuse of pesticides among vegetable farmers in control of tospoviruses in Zimbabwe. To overcome this, training needs to be widely implemented in IYSD-prone areas to empower farmers with knowledge and advice on the appropriate control measures to undertake as soon as the disease is identified.

A significant number of farmers $(23.4 \%)$ did not apply any control measure against IYSD infected onion plants. This allowed onion thrips vectors to feed on the infected plants and further spread the disease from one field to another. Farmers should therefore monitor onion thrips population using blue sticky traps and control them before they acquire and transmit the disease.

This study has recorded seven red onion varieties (Jambar F1, Islero, Red creole, Red Passion, Red Pinnoy, Bombay red, Red Tropicana) as the most farmer preferred (77.9\%). This provides an opportunity for 
these preferred varieties to be screened for IYSD and onion thrips resistance. Farmers generally preferred these red varieties due to high yielding capacity/large bulb size, early maturity, strong pungency, marketability and long shelf life. These observations are in agreement with those made by Osman et al. (2008), who evaluated the farmers' preferred characteristics of onion in Netherlands.

High Iris yellow spot disease incidence and severity was recorded in low and mid altitude regions (Figs. 2 and 3, respectively), possibly due to low knowledge of IYSD that resulted in inappropriate disease management strategies such as application of fungicides and no control measures against IYSD. Additionally, it could be as result of farmer's preference of red varieties such as Red creole, Bombay red and Red Pinnoy that are highly susceptible to thrips infestation and IYSD infection. Low IYSD incidence and severity in high altitude AEZ could be as a result of cultivation of white Texas Grano variety that is less susceptible to thrips infestation and IYSV infection by majority of farmers. The findings of the study concur with earlier reports by Diaz Montano et al. (2010) and Birithia et al. (2014), who reported majority of red onion varieties commonly grown New York and Kenya respectively were susceptible to onion thrips and IYSD infection.

\section{CONCLUSION}

This study has established that farmers in the three major onion growing agro-ecological zones of Kenya acknowledge existence of Iris yellow spot disease, but are unaware of the disease vectors resulting in inappropriate control measures. Therefore, they often attempt to control them using pesticides and fungicides. Thus, there is need for farmer training on IYSD identification and epidemiology to enable the implement appropriate control measures. Red onion varieties are the most preferred based on five most commonly stated preference criteria; high yielding/large bulb size, early maturity time, strong pungency, marketability and long shelf life. To ensure that IYSD-resistant varieties are adopted by farmers, recommended onions varieties need to be thoughtfully aligned with the traits desirable to onion farmers in each region.

\section{ACKNOWLEDGEMENT}

The authors wish to acknowledge onion farmers for generously sharing the knowledge and opinions.

\section{REFERENCES}

Birithia, R., Subramanian, S., Pappu, H.R., Muthomi, J.W. and Narla, R.D. 2014. Resistance to Iris yellow spot virus and onion thrips among onion varieties grown in Kenya. International Journal of Tropical Insect Science 34: 73-79.

Diaz-Montano, J., Fuchs, M., Brian, A.N. and Anthony, M.S. 2010. Evaluation of onion cultivars for resistance to onion thrips (Thysanoptera: Thripidae) and Iris yellow spot virus. Journal of Economic Entomology 103:925-937.

FAOSTAT. Food and Agriculture Organization of the United Nations. Crop Production Data, 2016, Rome. (Accessed September, 2019) Available: https://www.faostat.fao. org/faost at/en/\#data/QC

Fox, M., Ligges, U., Messad, S., Maechler, M., Muenchen, R., Murdoch, D., Neuwirth, E.,Putler, D., Ripley, B., Ristic, M. and Wolf, P. 2009. Rcmdr: R Commander. $\mathrm{R}$ package version 1.5-3. http://CRAN.R project.org/package= Rcmdr

Gent, D.H., du Toit, L.J., Fichtner, S.F., Mohan, K.S., Pappu, H.R and Schwartz, H.F. 2006. Iris yellow spot virus: an emerging threat to onion bulb and seed production. Plant Disease 90:1468-1480.

Griffith, G. Trueman, L., Crowther, T., Thomasm, B. and Smith, B. 2002. Onions 
- A global benefit to health. Phytotherapy Research 16 (7):603-615.

Hamed, T. 2017. Determining sample size: How to calculate survey sample size. International Journal of Economics and Management System, IARAS, 2017. ffhal02557333f

Karavina, C., Munyati, V.T. and Gubba, A. 2017. Knowledge and perceptions of plant viral diseases by different stakeholders in Zimbabwe's agricultural sector: Implications for disease management. African Journal of Agricultural Research 12(21):1832-1840.

Kibayu, S. 2009. A survey of production practices and evaluation of onion varieties susceptibility to thrips in Kirinyanga district, Kenya. M.Sc. Thesis, Jomo Kenyatta University of Agriculture and Technology, Nairobi, Kenya. 120pp.

Kritzman, A., Lampel, M., Raccah, B.A. and Gera, A. 2001. Distribution and transmission of Iris yellow spot virus. Plant Disease 85:838-842.

Mandal, B., Jain, R.K., Krishnareddy, M., Krishna Kumar, N.K., Ravi, K.S. and Pappu, H.R. 2012. Emerging Problems of Tospoviruses (Bunyaviridae) and their Management in the Indian Subcontinent. Plant disease 96(4):468-479.

MOA. 2018. Ministry of Agriculture Provincial Horticultural Production Statistics 20172018. Nairobi, Kenya.

Nabuzale, R. 2014. Effect of farmer's knowledge and attitudes on management of the tomato spotted wilt virus in Sironko District. M.Sc. Thesis, Makerere University, Kampala, Uganda. 48pp.
Nagaraju, N., Venkatesh, H.M., Warburton, H., Muniyappa, V., Chancellor, T.C.B. and Colvin, J. 2002. Farmers' perceptions and practices for managing tomato leaf curl virus disease in south-ern India. International Journal Pest Management 48 (4):333-338. https://doi.org/10.1080/ 09670870210153164.

Osman, A.M., Almekinders, C.J.M., Struik, P.C and Lamerts van Bueren, E.T. 2008. Can conventional breeding programmes provide onion varieties that are suitable for organic farming in the Netherlands? Euphytica 163:511-522.

Pappu, H.R., Jones, R.A.C. and Jain, R.K. 2009. Global status of tospovirus epidemics in diverse cropping systems: successes achieved and challenges ahead. Virus Research 141(2): 219-236.

Pareek, S., Kumar, V., Sharma, S. and Sagar, N.A. 2017. Onion (Allium cepa L.). Food Chemistry 52(5):1174-1131.

Schreinemachers, P., Balasubramaniam, S., Boopathi, N.M., Viet, Ha. C, Kenyon, L, Praneetvatakul, S., Sirijinda, A., Tuan, Le, N., Srinivasan, R. and Wu, M.H. 2015. Farmers' perceptions and management of plant viruses in vegetables and legumes in tropical and subtropical Asia. Crop Protection 75:115-123. https://doi.org/ 10.1016/j.cropro.2015.05.012

Syller, J. 2012. Facilitative and antagonistic interactions between plant viruses in mixed infections. Molecular Plant Pathology 13 (2):204-216. https://doi.org/10.1111/ j.1364-3703.2011.00734.x 